\title{
THE INFLUENCE OF SERVANT LEADERSHIP ON ORGANIZATIONAL CITIZENSHIP BEHAVIOR: THE MEDIATING EFFECT OF ORGANIZATIONAL COMMITMENT
}

Mohammad Harisur Rahman Howladar, Md Sahidur Rahman

\section{Abstract}

The main aim of the study to find out whether organizational commitment has any mediation effect on the relationship between servant leadership and organizational citizenship behavior. Data was collected from 432 managers and staff of private commercial banks in Bangladesh. The respondents were selected using the convenience sampling technique. Structural equation modeling was used for analyzing the collected data. The study reveals that servant leadership has a direct influence on organizational commitment and organizational citizenship behavior, as well as organizational commitment has a direct impact on organizational citizenship behavior. It is also revealed that the relationship between servant leadership and organizational commitment is partially mediated by organizational commitment. The main implication of the study is that employees' organizational citizenship behavior can be improved by servant leadership of managers through the indirect effect of organizational commitment of employees. The study also pinpoints some limitations as well as future research directions.

Keywords: Organizational commitment, Servant Leadership, Organizational citizenship behavior, Mediation.

JEL Classification: C31, C88, L29, M10

\section{INTRODUCTION}

Servant leadership (SL) instigated for change in traditional ideas of leadership and prepares the organizations for facing the ambiguous future (McGee-Cooper and Looper 2001). SL emphasizes the more democratic and learning-based style of leadership rather than hierarchical and power-oriented leadership (Lloyd 1996). It is an acceptable theory of leadership for individual and organizational levels, which increases the performance of teams and individuals (Lee et al. 2019; Parris and Peachey 2013).

In today's competitive business world managers need to apply those leadership approaches that can ensure the committed workforce (Bučiūnienè and
Mohammad Harisur Rahman Howladar, PhD

(corresponding author)

Professor

Department of Management

University of Chittagong, Bangladesh

Email: harisur@cu.ac.bd

Address: University of Chittagong, Chottogram,

Bangladesh

ORCID: https://orcid:org/0000-0003-2302-5561

Md Sahidur Rahman, PhD

Professor

Department of Management

University of Chittagong, Bangladesh

Email: sahidur_cu@yahoo.com 
Škudienè 2008) and employees who work not only within their boundary but also proactively out of their boxes for up-bringing organizations. Committed and proactive employees can ensure the competitiveness of the organizations (Yen and Teng 2013). The development of favorable working environments is essential for creating committed teams and their performance (Haque, et al. 2019). SL has a positive influence on both organizational commitment (OC) (Bobbio, Dierendonck, and Manganelli 2012; Van Dierendonck and Nuijten 2011; Zhou and Miao 2014) and organizational citizenship behavior (OCB)(Abid, Gulzar, and Hussain 2015; Bobbio et al. 2012; Yang and Min 2013). It was also found that when the employees are committed they show their intention to do extra for the organizations (Lawrence, Ott, and Bell 2012; Najafi el al. 2011; Ng and Feldman 2011).

Most of the studies on SL, OC, and OCB were conducted in the Western context. Only a few studies (Abid et al. 2015; GÜÇEL and Begec 2012; Mathur and Negi 2014; Newman et al. 2017) were found in Asian countries. There were no studies found in India (Carroll and Patterson 2016; Kashyap and Rangnekar 2014), Turkey (Cerit 2009; Koyuncu et al. 2014), China (CH Chan and Mak 2014; Liu, Hu, and Cheng 2015), Malaysia (Le Ng, Choi, and Soehod 2016; Ramli and Desa 2014) and Singapore (Zhang, Lin, and Fong Foo 2012) that focused on SL, OC and OCB together. Additionally, so far as our knowledge goes such studies are not found in Bangladesh.

Banking is one of the larger service sectors in Bangladesh, where most of the staff are highly educated. Dealing with highly educated and technical people is very crucial for the success of organizations. SL can be the best option for managers of different banks to deal with competent banking staff. SL studies in any South Asian country did not include the banking sector as their context. Most of the studies focused on IT employees (Carroll and Patterson 2016), teaching staff (Cerit 2009; Zhang et al. 2012) private employees (CH Chan and Mak 2014), and public employees (Liu et al. 2015).

Moreover, some studies revealed the direct influence of SL on OC and OCB, while other studies found a direct influence of $O C$ on $O C B$. The question arises, whether the relationship between $S L$ and $O C B$ can be mediated by OC. Surprisingly, the impact of $O C$ on the association between SL and OCB is not adequately examined. Hence, this research gap motivates the researchers to expose whether the impact of SL on OCB can be mediated by OC.

The present study can contribute by advancing the existing knowledge in numerous ways. First, this study will unearth the impact of SL on OC and OCB in the developing countries' context more specifically in Bangladesh. Second, the present study examines the suitability of SL for the managers in the banking sector in developing countries like Bangladesh to increase commitment and extra-role behavior. Third, the existing literature is loaded with a discussion on the role of SL on OC and OCB. This study tends to reveal whether the influence of $S L$ on OCB can be mediated by $\mathrm{OC}$, which is not tested elsewhere by the researchers according to our knowledge.

\section{LITERATURE REVIEW}

\subsection{Servant leadership (SL)}

Going beyond one's self-interest is the main characteristic of SL (Greenleaf 1970). Servant leaders are not looking for power rather they are inspired by serving others (Luthans and Favolio 2003). Servant leaders outstrip self-interest.

Servant leaders are developing people, sharing leadership, displaying authenticity, valuing people, providing leadership, and building community (Laub 1999). Similarly, Wong and Page (2003) mentioned that SL is visionary leadership, servanthood, responsible leadership, courageous leadership, as well as they are emphasizing honesty, authenticity, power, and pride ( vulnerability and humidity) and developing and empowering others. To lead a team effectively SL provides accountability, gives support, emphasizes true self-evaluation, fosters collaboration, provides clear information, and values the people (Irving and Longbotham 2007).

Moreover, empowerment, standing back, accountability, forgiveness, courage, authenticity, humility, and stewardship are the constructs of SL which are confirmed by Van Dierendonck and Nuijten (2011). The operational definition of SL given by Van Dierendonck and Nuijten is adopted in this study.

\subsection{Organizational commitment (OC)}

Organizational commitment is the relative strength of a person's identification with and participation in a certain organization (Porter et al. 1974).

From the relationship point of view, OC refers to the condition in which an employee identifies himself/herself with the organization and its goals and desires to continue the affiliation in the organization (Miller 2003). There is another approach to defining 
OC is behavior (Morrow 1993). According to the behavioral approach, OC is the visible behavior of an individual when he/she is committed to the existing group within the organization (Reichers 1985).

OC has three dimensions (Mayer and Allen 1991). These dimensions (Affective, continuance, and normative commitment) are distinguishable and can feel by the employee with varying degrees (Meyer and Allen 1991). Multidimensionality of OC and its measurement was held up by a Meta-analysis (Allen and Meyer 1996). This study adapted Meyer and Allen's concept of OC.

\subsection{Organizational citizenship behavior (OCB)}

Organizational citizenship behavior (OCB) is not the portion of the official job behavior but useful for the organization (Smith, Organ, and Near 1983). Besides, D. Organ (1988) mentioned that this is an optional behavior of a person, not rewarded formally, but in total, this upholds the organizational effectiveness.

The five dimensions of OCB suggested by D. Organ (1988) are altruism, sportsmanship, conscientiousness, courtesy, and civic virtue. The scale of OCB developed by Podsakoff et al. (1990) has five subscales for each dimension given by Organ. This five-dimensional scale was adopted by the current study.

OCB-I and OCB-O are two different dimensions of OCB (Williams and Anderson 1991). OCB-I is citizenship behavior focused on individuals. Helping others when people are in a heavy workload, helping new people to understand their jobs, are examples of OCB -I. On the other hand, OCB-O is the extra-role behavior focused on the organization. When employees not complaining to others at work, protecting the organizational resources for the organizational wellbeing, then these activities of the employees are under OCB-O. In other cases, behavior-based OCB taxonomies are proposed and operationalized by many researchers (Borman and Motowidlo 1993; Morrison 1994; Vandyne, Cummings, and Parks 1995). But the behavior-based OCB taxonomies are overlapping with each other and with Organ's (1988) OCB dimensions (Coleman and Borman 2000).

\subsection{Servant leadership and organizational citizenship behavior}

A good number of studies revealed that SL has a significant positive relationship with OCB (Abid et al. 2015; Bobbio et al. 2012; Yang and Min 2013). Liden et al. (2008) developed 28 items of SL instrument and ensured validity by showing that SL caused more variance in OCB than other leadership styles. Some other empirical studies in India (Mathur and Negi 2014), Kenia (Walumbwa, Hartnell, and Oke 2010), China (Newman et al. 2017), and Turkey (GÜÇEL and Begec 2012) revealed a significant direct influence of $S L$ on OCB. From the above discussions and the summary of the findings, it is postulated that SL has a direct influence on OCB. Therefore, we can develop the hypothesis as follows:

$\mathrm{H}_{1}$ : There is a direct influence of SL on OCB.

\subsection{Servant leadership and organizational commitment}

In the western countries' context, some empirical studies (Bobbio et al. 2012; Lapointe and Vandenberghe 2018; Newman et al. 2018) revealed that there is a positive influence of SL on OC. Conversely, Drury (2004) found that there is an inverse influence of SL on OC. Miao et al. (2014) revealed that affective and normative commitment is positively affected by $\mathrm{SL}$, but SL has no influence on continuance commitment. Awee et al. (2014) and Ramli and Desa (2014) studied in Malaysia and revealed that SL has a positive influence on OC. Though there are some controversies in different findings, many studies showed a positive influence of SL on OC. From the above discussions, it can be perceived that there is a direct influence of SL on OC. Hence, the hypothesis can be developed as follows:

$$
\mathrm{H}_{2} \text { : There is a direct influence of SL on OC. }
$$

\subsection{Organizational commitment and organizational citizenship behavior}

Moorman, Niehoff, and Organ (1993) revealed that OC has a significant positive impact on OCB. Meyer et al. (2002) demonstrated that one of the outcomes of $O C$ is $O C B$. Another study in a university environment found that $O C$ influences OCB (Mirabizadeh and Gheitasi 2012). Chen and Francesco (2003) revealed that affective commitment (AC) is positively related to $O C B$, but continuance commitment $(C C)$ and $O C B$ are negatively correlated. In a study, Zeinabadi (2010) revealed that commitment mediates the association between job satisfaction and OCB. Some studies in Bangladesh also found that $O C$ has a positive impact 
on OCB (Ferdus and Kabir 2018; Jahangir, Akbar, and Begum 2006). Some recent studies (Obedgiu, Bagire, and Mafabi 2017; op den Buijs et al. 2019; Pooja, De Clercq, and Belausteguigoitia 2016) found the similar results. Thus, it can be perceived that OC can positively influence OCB. Therefore, we can suggest the following hypothesis:

$\mathrm{H}_{3}$ : There is a direct influence of OC on OCB.

\subsection{Servant leadership, Organizational citizen- ship behavior, and organizational commitment}

Empirical studies in the area of OCB, SL, and OC gave attention to find out the association between $S L$ and OC (Bobbio et al. 2012; Lapointe and Vandenberghe 2018; Newman et al. 2018) and the influence of SL on OCB (Abid et al. 2015; Bobbio et al. 2012; Newman et al. 2017). Many studies revealed that SL has a positive influence on OCB and OC. No study revealed the mediating influence of $O C$ on the association between SL and OCB. Walumbwa et al. (2010) showed that employees' commitment to their supervisor mediates the association between SL and OCB. Since SL can positively influence both $O C$ and $O C B$, and $O C$ is one of the antecedents of OCB (Lawrence et al. 2012; Najafi et al. 2011; Ng and Feldman 2011; D. W. Organ, Podsakoff, and MacKenzie 2005), then it can be perceived that OC can mediate the relationship between SL and OCB. Hence, we can develop the following hypothesis:

$\mathrm{H}_{4}$ : OC can mediate the relationship between SL and OCB.

Based on the previous hypotheses, the following research model can be developed(Cheung and Lau 2008; Hopwood 2007):

Figure 1. Research model

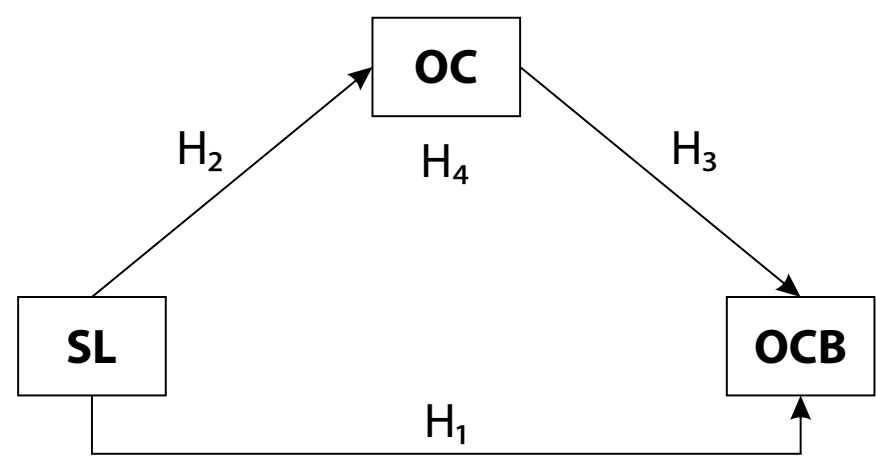

\section{RESEARCH METHODS}

\subsection{Sample and data collection}

All the managers and staff working in private commercial banks (PCBs) of Bangladesh are involved in the population of this study. The total number of managers and staff serving the PCBs is more than one hundred thousand (Ahmed and Rahman 2020). For collecting primary data from the sample of managers and staff, the convenience sampling method is supposed to be the best fit. To save time and money convenience sampling is commonly used in social research and organizational studies (Bryman 2016).

Accordingly, PCBs are selected using the quota sampling technique. Quota sampling is used for confirming the presence of respondents from diverse categories of PCBs (traditional interest-based banks, Islami sharia-based banks, etc.). Selected banks and branches are chosen using quota sampling and then respondents from different banks and branches are reached using a convenient sampling method.

Sample size 321 is appropriate for the population of 100.000 at $95 \%$ confidence level and error $+/-5 \%$ is allowed (Zikmund et al. 2013). On the other hand, Saunders, Lewis, and Thornhill (2009) mentioned that the sample size should be 384 in the same situation.

Methods used for data analysis also influence the choice of sample size. A large sample size is expected for the use of Structural equation modeling (SEM). The sample size should be $150-400$ for better results of SEM (Hair et al. 2012). The sample size 400 was considered most appropriate for this study on the ground that population size is more than 100,000 and collected data was analyzed using SEM.

Data was collected from the respondents with a time gap to avoid the common method variance (CMV). In the first stage, personal data and data related to SL were collected. After three weeks, the respondents were supplied the second part of the survey instrument to measure $O C$ and $O C B$.

A team of ten graduate students was used for collecting data from different PCBs situated at different geographical areas after giving appropriate training. The authors of the current study provided all sorts of financial assistance to all the team members. Despite this, the authors personally distributed some questionnaires among the respondents of some selected PCBs where no team members got access.

432 respondents were returned the questionnaire out of 500 distributed questionnaires. Among them, 387 were usable. Some completed questionnaires were rejected due to problems of severe outliers, unengaged responses, and missing data. The response rate is $77.4 \%$. This response rate is adequate (Baruch 
and Holtom 2008; Saunders et al. 2009; Zikmund et al. 2013).

$82.7 \%$ of respondents of this study are male $(320$ in numbers). Among the respondents $43.2 \%$ belong to the $30-35$ age, $34.1 \%$ respondents were within $25-30$ age, and only $14.0 \%$ were within $35-40$ age. Most of the respondents are highly educated $(96.4 \%$ of respondents were master holders). Among the respondents $23.5 \%$ were assistant officers, $23.8 \%$ were officers, $11.6 \%$ were principal officers, and $37.2 \%$ were senior officers. Most of the respondents (42.4\%) had 3 -6 years of work experience. 1-3 years work experience had $28.7 \%$ of respondents, $16.8 \%$ had $6-9$ years work experience, and $12.1 \%$ had above 9 years work experience. 143 respondents (37\%) had work experience with their present manager for 1-2 years. Moreover, $12.7 \%$, had 1-year work experience with their present manager, $27.1 \%$ had $2-3$ years, and $28.2 \%$ had above 3 years work experience with their present manager. Out of 387 respondents, 257 respondents (66.4\%) were married.

\subsection{Measurement tools}

The 30-item SL scale of Van Dierendonck and Nuijten (2011) was used to measure SL since this scale showed high reliability and validity. This scale has eight dimensions such as accountability, forgiveness, courage, empowerment, humidity, standing back, authenticity, and stewardship. Three items (14, 15, and 16) were negatively keyed. The seven points Likert scale was used for getting the responses on items. In the present context, it was found good reliability ranged from .772 to .893 .

The OC scale given by Allen and Meyer (1990) was used for measuring OC. This scale contains 18 items divided into three subscales according to the dimensions of OC. The seven points Likert scale was used for getting the responses on items. Reliability scores of this scale in the current context were found from .875 to .884 which indicates very good reliability.

To measure the OCB the scale given by Podsakoff et al. (1990) was used which generated one global measure of OCB. There are five dimensions of this scale such as conscientiousness, sportsmanship, civic virtue, altruism, and courtesy. Only five items were negatively keyed $(2,4,7,16$, and 19$)$. The seven points Likert scale was used for getting the responses on items. The reliability scores of this scale ranged from .825 to .885 which also indicates very good reliability of this scale in the current context.

\subsection{Evaluation of model}

Both the measurement model and the structural model were examined by using SEM (Hair et al. 2012). SEM takes a confirmatory approach, can include both manifest and latent variables, and estimate measurement error (Hair et al. 2012; Hoe 2008).

\subsubsection{Measurement model}

The exactness of the model was examined by reliability and validity checks including convergent validity and discriminant validity. From Table 1, it is found that the factor loadings have a satisfactory value that is above the minimum level of 0.50 for each item of the constructs (Hair et al. 2012). Moreover, the internal consistency measurement through Cronbach's alpha (From .772 to .893) and composite reliability (From .773 to .889 ) indicates the reliability of the scales (Hair et al. 2012).

To evaluate the validity of the measurement models, both the convergent and discriminant validities were advocated (Hair et al. 2012). From Table 1, it is found that the minimum average variance extracted (AVE $=.539)$ and composite reliability $(C R=.773)$ are above the threshold value of .0500 and 0.700 respectively (Hair et al. 2012; Saunders et al. 2009) that confirmed the convergent validity of the measurement models. From table 2, it is found that the interconstruct correlation is smaller than the square root of AVE. This finding demonstrates the existence of the discriminant validity of the scales. Moreover, from table 1 , it is found that the factor loading is more than 0.70 for each construct that also confirms the discriminant validity of the scales (Haque et al. 2019; Kline 2005).

According to the Harman's single factor test, the current study has a concern for common method bias since this model has a very poor fit $\left(\mathrm{X}^{2} / \mathrm{df}=9.479\right.$, GFI $=.692, \mathrm{NFI}=.627, \mathrm{CFI}=.650, \mathrm{TLI}=.596$, and RMSEA $=$ .148) (Podsakoff, et al. 2003). After applying the unmeasured latent method factor (Podsakoff, MacKenzie, and Podsakoff 2012), it is found that the model has satisfactory fit for the data $\left(\mathrm{X}^{2} / \mathrm{df}=1.558, \mathrm{GFI}=.960\right.$, $\mathrm{NFI}=.950, \mathrm{CFI}=.981, \mathrm{TLI}=.973$, and $\mathrm{RMSEA}=.038)$ with the common method factor. Moreover, the common methods factor causes variance extraction only by $23.35 \%$ which is less than the minimum level of $50 \%$. Thus, the present study has no serious concern for common method bias (Kashyap and Rangnekar 2014; Podsakoff et al. 2012).

Furthermore, Table 1 shows that the overall measurement model bestowed a good fit to the data $\left(X^{2} / \mathrm{df}\right.$ 
Table 1. Constructs reliability and validity

\begin{tabular}{|c|c|c|c|c|c|}
\hline $\begin{array}{l}\text { Exogenous } \\
\text { constructs }\end{array}$ & Latent constructs & $\begin{array}{c}\text { Standard Factor } \\
\text { loading }\end{array}$ & Cronbach's alpha & $\begin{array}{l}\text { Composite } \\
\text { reliability }\end{array}$ & AVE \\
\hline \multirow[t]{8}{*}{$\mathrm{SL}$} & Empowerment & .81 & .883 & 0.889 & 0.667 \\
\hline & Standing Back & .78 & .884 & 0.885 & 0.719 \\
\hline & Accountability & .74 & .831 & 0.833 & 0.624 \\
\hline & Forgiveness & .76 & .772 & 0.773 & 0.630 \\
\hline & Courage & .75 & .785 & 0.792 & 0.658 \\
\hline & Authenticity & .75 & .865 & 0.866 & 0.617 \\
\hline & Humility & .78 & .893 & 0.885 & 0.608 \\
\hline & Stewardship & .82 & .843 & 0.845 & 0.645 \\
\hline \multirow[t]{3}{*}{ OC } & Continuous & .68 & .875 & 0.877 & 0.544 \\
\hline & Affective & .86 & .883 & 0.876 & 0.540 \\
\hline & Normative & .77 & .884 & 0.886 & 0.565 \\
\hline \multirow[t]{5}{*}{ OCB } & Altruism & .84 & .884 & 0.832 & 0.554 \\
\hline & Conscientiousness & .78 & .836 & 0.885 & 0.607 \\
\hline & Courtesy & .79 & .829 & 0.841 & 0.572 \\
\hline & Sportsmanship & .72 & .853 & 0.853 & 0.539 \\
\hline & Civic Virtue & .79 & .825 & 0.825 & 0.541 \\
\hline
\end{tabular}

Note: * fixed parameter, AVE = Average variance extracted

Source: Authors' calculation, 2020

Table 2. Inter-construct correlations and the Square root of AVE

\begin{tabular}{|c|c|c|c|c|c|}
\hline & CR & AVE & OC & SL & OCB \\
\hline OC & 0.761 & 0.517 & $\mathbf{0 . 7 1 9}$ & & \\
\hline SL & 0.892 & 0.510 & 0.363 & $\mathbf{0 . 7 1 4}$ & \\
\hline OCB & 0.843 & 0.518 & 0.366 & 0.388 & $\mathbf{0 . 7 2 0}$ \\
\hline
\end{tabular}

Diagonal bold figures are the square root of AVE; sub diagonal figures are the inter-construct correlations.

Source: Authors' calculation, 2020

$=1.588, \mathrm{RMR}=0.051, \mathrm{GFI}=.952, \mathrm{NFI}=.940, \mathrm{CFI}=.977$, $\mathrm{TLI}=.972$, and RMSEA $=.039)$ since all the fit indices are within their standard value (Hair et al. 2012).

\subsubsection{Structural model}

After examining the reliability and validity, now move to test the structural model fitness. The structural model delivered a good fit to the data $\left(X^{2} / \mathrm{df}=1.588\right.$, $\mathrm{RMR}=.051, \mathrm{GFI}=.952, \mathrm{NFI}=.940, \mathrm{CFI}=.977, \mathrm{TLI}=.972$, and RMSEA = .039) (Hair et al. 2012). Though the NFI value is less than the standard value .95 but it is with acceptable level .90 (Hair et al. 2012).

The constructs of structure models are associated to each other. To find out the nature of these associations the path coefficient analysis is also used. The results from Table 3 revealed that SL and OC explain $21 \%$ variance in OCB $\left(R^{2}=0.21\right)$ and $S L$ explains $13 \%$ variance in OC $\left(R^{2}=0.13\right)$. Additionally, the results shown in Table 3 demonstrated a significant influence of SL on OCB $(\beta=.294, t=4.609, p=.000)$, and OC $(\beta=$ $.363, t=5.660, p=.000)$. Moreover, OC significantly influence the OCB $(\beta=.259, t=3.866, p=.000)$. Thus $H_{1}$, $\mathrm{H}_{2}$ and $\mathrm{H}_{3}$ are supported. 
Figure 2. $O C$ partially mediating the relationship between $S L$ and $O C B$

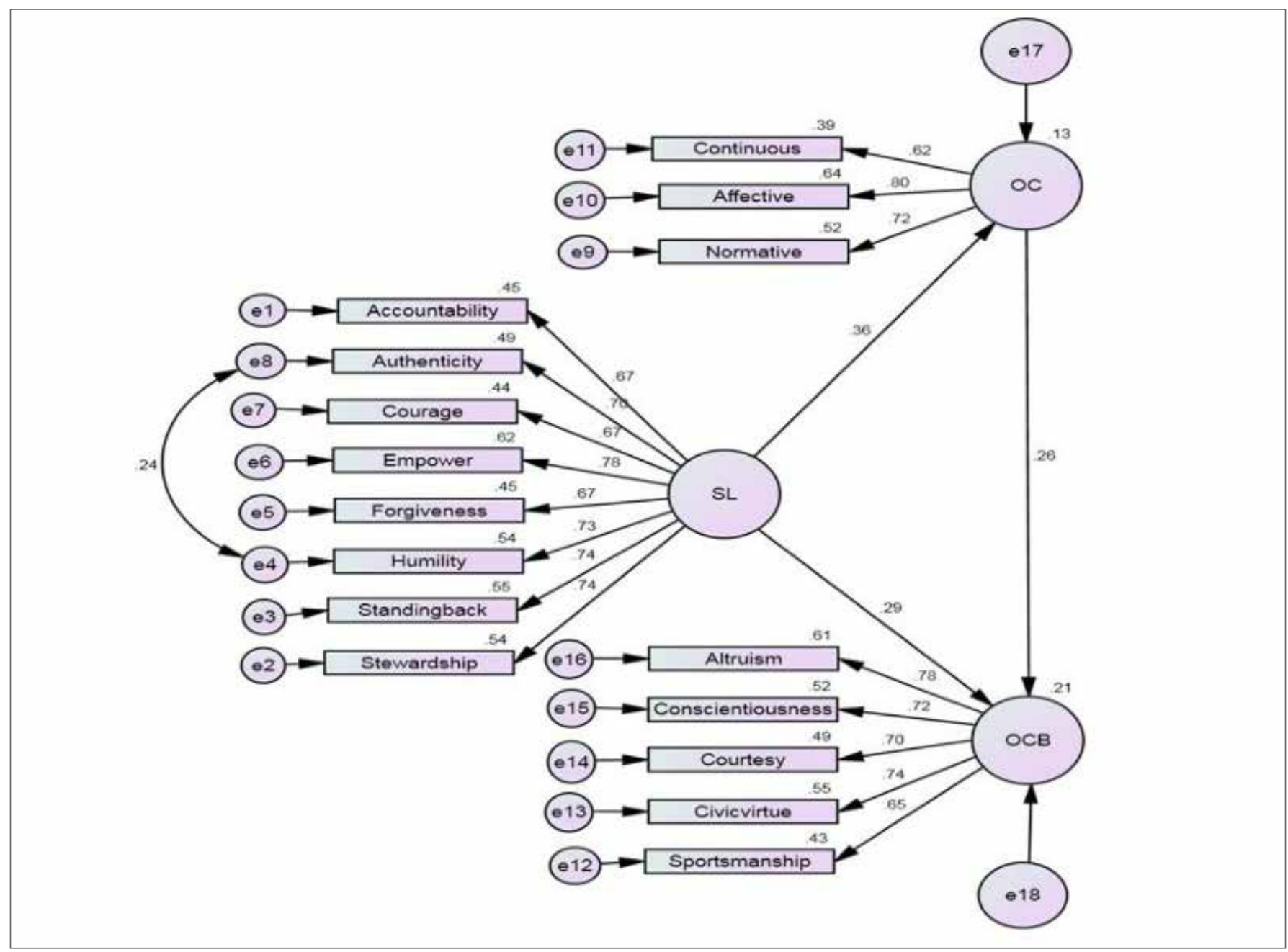

Source: Authors' development, 2020

Table 3. Test of Hypotheses for the structured model

\begin{tabular}{|c|c|c|c|c|c|}
\hline Hypothesis & $\begin{array}{c}\text { Hypothesized } \\
\text { relationship }\end{array}$ & $\begin{array}{c}\text { Standardized } \\
\text { coefficient }\end{array}$ & T-value & P-value & Result \\
\hline H1 & SL $\rightarrow$ OCB & .294 & 4.609 & .000 & Supported \\
\hline H2 & SL $\rightarrow$ OC & .363 & 5.660 & .000 & Supported \\
\hline H3 & OC $\rightarrow$ OCB & .259 & 3.866 & .000 & Supported \\
\hline
\end{tabular}

Source: Authors' calculation, 2020

\section{RESULTS}

\subsection{Mediation testing}

The nested models' approach was used for testing mediation. In this approach, the partially mediated model is compared with the most likely competing models nested within it (Brown et al. 2002; Cantarello, Filippini, and Nosella 2012; Ju Rebecca Yen and Gwinner 2003).

The outcomes of three different models are shown in table 4. The first model is the partial mediating model shows both the direct and indirect impact of SL on OCB (Figure 2). The second model is a full mediating model where it is shown that the association between SL and OCB is mediated by OC (Figure 3). 
Figure 3. OC fully mediating the relationship between $S L$ and $O C B$

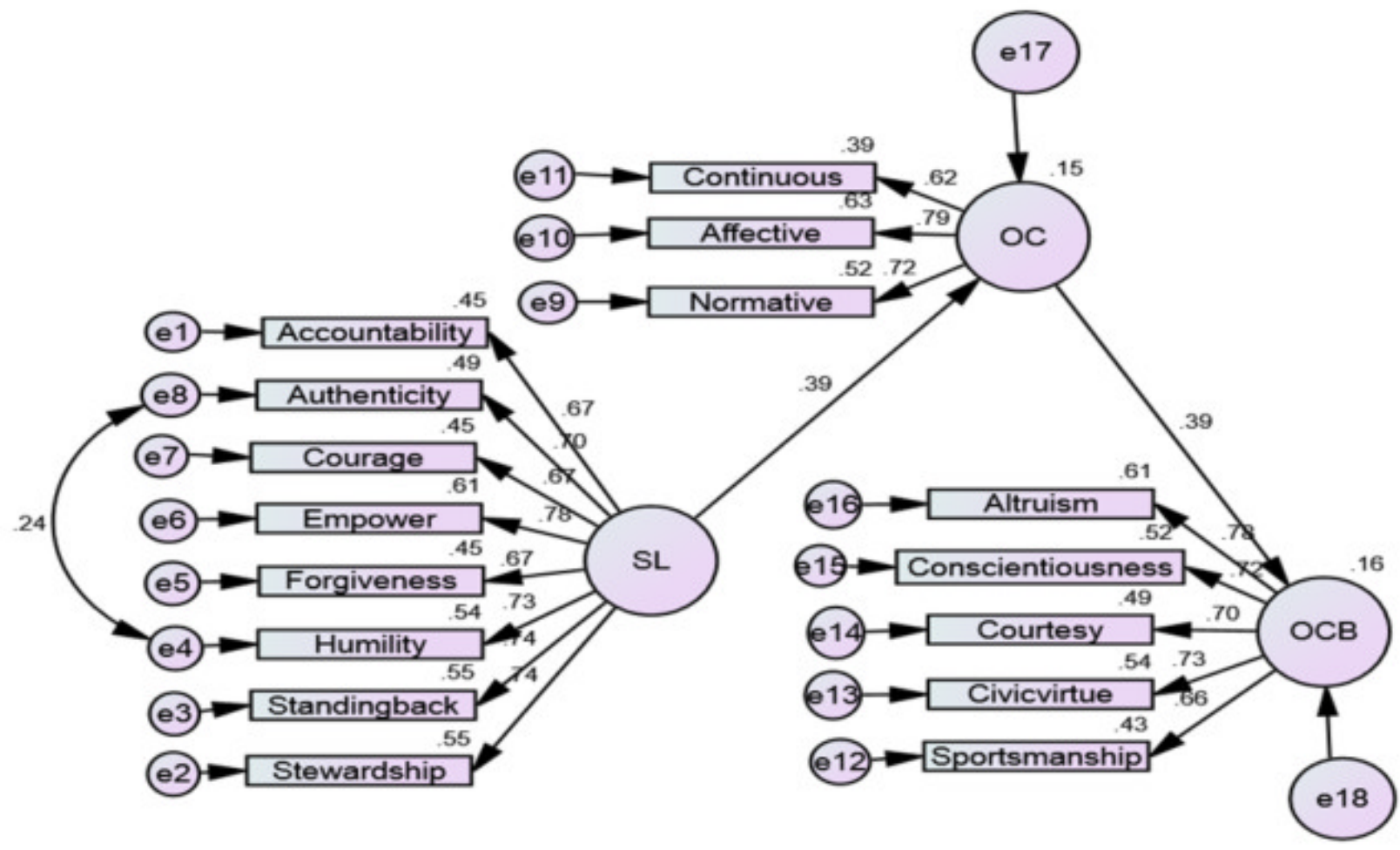

Source: Authors' Development, 2020

Table 4. Fit indices of the models

\begin{tabular}{|l|l|l|l|l|l|l|}
\hline Model & X2/df & CFI & GFI & NFI & TLI & RMSEA \\
\hline First (Partial mediating) & 1.588 & .977 & .952 & .940 & .972 & .039 \\
\hline Second (Full mediating) & 1.802 & .968 & .946 & .931 & .962 & .046 \\
\hline Third (Direct relations) & 1.938 & .962 & .942 & .926 & .955 & .049 \\
\hline
\end{tabular}

Source: Authors' calculation, 2020

The third model is the direct effect model where the direct impact of $S L$ and OC on OCB is shown (Figure 4). The partial mediating model is needed to compare with both the full mediating model and the direct effect model to examine the nature of mediating effect of OC on the association between SL and OCB. Table 4 shows the comparison of three models based on the fit indices.

According to the fit indices, table 4 revealed that all three structural models are well fit. But the partial mediation model shows better fit indices than the other two models. The $\mathrm{X}^{2}$ difference test is conducted. The result shows that the $X^{2}$ difference between the first model (partially mediating) and the second model (fully mediating) $\left(X^{2}\right.$ difference $=23.237, \mathrm{df}=$ $1, p=0.000$ ) is significant as well as the $X^{2}$ difference between the first model (partially mediating) and the second model (direct effect) $\left(X^{2}\right.$ difference $=36.950, \mathrm{df}$ $=1, p=0.000$ ) is also significant. Thus it is found that the partially mediated model is best fitted. The results recommend that $\mathrm{OC}$ has a partial mediation impact on the association between SL and OCB. Therefore, 
Figure 4. The direct relationship of SL and $O C$ with $O C B$

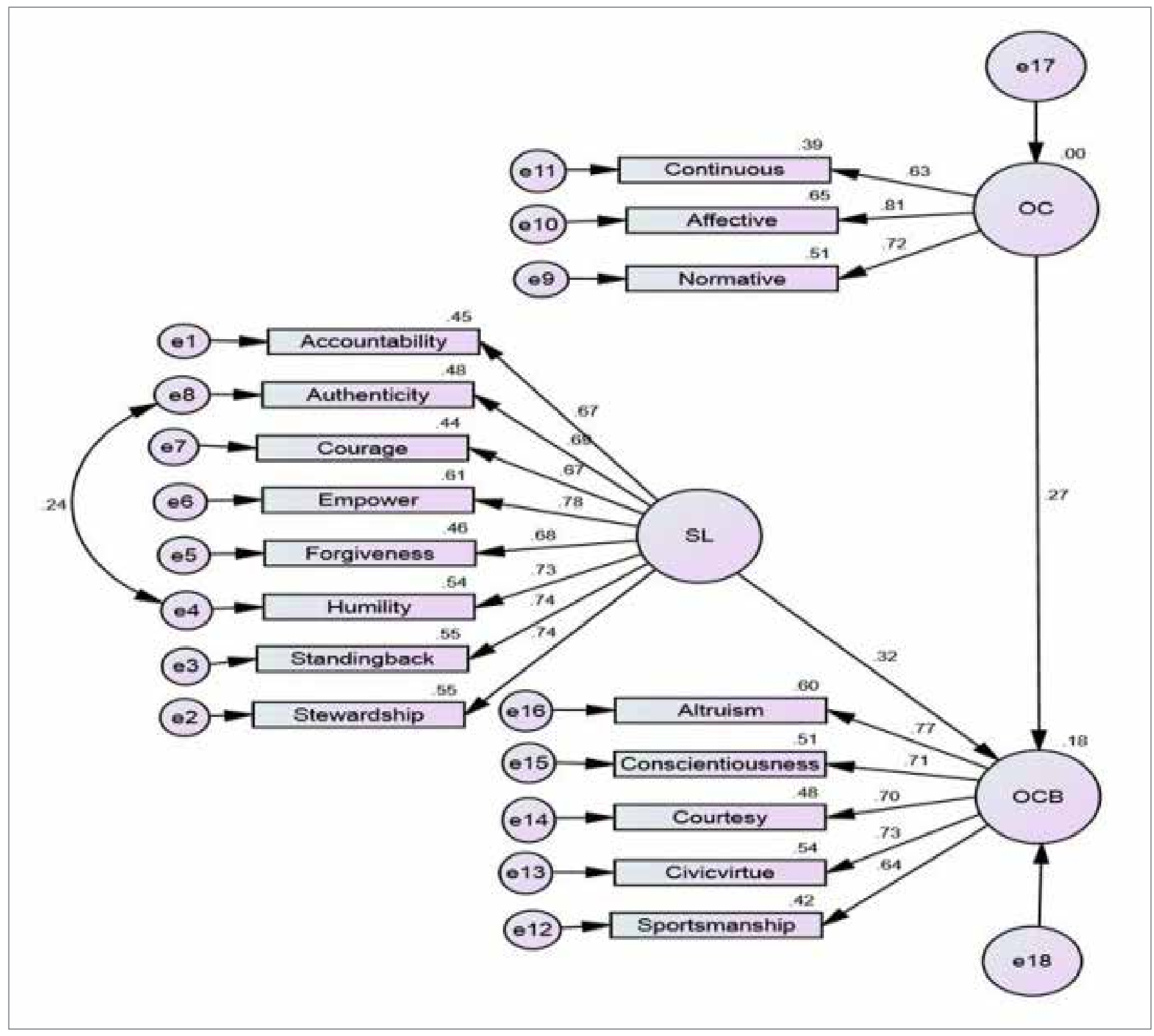

Source: Authors' development, 2020

hypothesis $\mathrm{H}_{4}$ is supported. Thus, it could be stated that SL has both direct and indirect effects on OCB. The proportion of mediation of OC on the SL and OCB relationship is found 24.40 percent $[(.36 \times .26) /(.36 \times$ .26) + .29] (lacobucci, Saldanha, and Deng 2007). The result indicates that $24.40 \%$ variance on OCB is explained by both $S L$ and $O C$ which is for the indirect path via $O C$, whereas the remaining $O C B$ variance is explained by both $S L$ and $O C$ which is for the direct path. Hence, there is a partial mediation because the direct path is preponderated.

\section{DISCUSSION}

The result of this study revealed that there is a direct influence of SL on OCB. This result is also reinforced by other findings in the Western context (Neubert et al. 2008; Reed 2016; Van Dierendonck et al. 2017) as well as in the Asian context (Abid et al. 2015; GÜÇEL and Begec 2012; Newman et al. 2017). Some studies (Abid et al. 2015; Hu and Liden 2011) in the banking sector also support the direct influences of SL on OCB.

Additionally, the outcome of the current study revealed that there is a direct impact of SL on OC. 
This result is also supported by other outcomes in the Western context (Bobbio et al. 2012; Drury 2004; Lapointe and Vandenberghe 2018). In developing countries, some studies (Awee et al. 2014; Miao et al. 2014; Ramli and Desa 2014) also support that SL has a direct influence on OC.

Moreover, it was perceived that there is a direct impact of $O C$ on $O C B$, and the finding of the present study supported this perception. This finding is also supported by Western studies (Cetin, Gürbüz, and Sert 2015; op den Buijs et al. 2019; Pooja et al. 2016) along with the developing countries (Obedgiu et al. 2017; Prasetio, Yuniarsih, and Ahman 2017). In Bangladesh, a study on bankers (Ferdus and Kabir 2018) also supports the direct influence of OC on OCB.

The relationship between $S L$ and $O C B$ is partially mediated by OC. This finding of the study is supported indirectly by the findings of Walumbwa et al. (2010) who studied employees' commitment to their supervisor. The mediation influence of $O C$ on the SL and $O C B$ relationship is partial due to a significant direct relationship of SL and OC with OCB. However, some other factors may influence the relationship between $S L$ and OCB that is still a matter of discovery.

\section{THEORETICAL AND PRACTICAL IMPLICATIONS OF THE STUDY}

The theoretical contribution of the study is that $O C$ indirectly affects the relationship between $\mathrm{SL}$ and $\mathrm{OCB}$ that was not identified by any other findings earlier. Moreover, the dimensions of SL are perfectly suited in developing countries' contexts like Western countries. SL style is similarly applicable in the developing countries like Bangladesh which is supported by other few findings in Asian and African countries like India (Carroll and Patterson 2016), Malaysia (Le $\mathrm{Ng}$ et al. 2016), China (Liu et al. 2015), Turkey (Cerit 2010), and Kenia (Walumbwa et al. 2010).

This study adds new knowledge by exploring the effect of SL on employees' OC and OCB in organizations. Based on the outcomes of the study it can be proposed that SL should be recognized as a significant antecedent to foster OC and OCB among employees.

It is found that the SL scale of van Dierendonck and Nuijten, (2011) is approachable and easily applicable in developing countries. These findings create opportunities for selecting and developing $S \mathrm{~L}$ in the organizations of developing countries through proper assessment, training, and performance evaluation of the executives.
Managers and executives can apply SL that ultimately will improve the employees' OC and OCB. The employee-orientated managers and executives are empowering the employees, developing them, and increasing loyalty. Hence, this leadership can improve the performance of both employees and organizations in today's technology-based extremely competitive business situation.

Like other service organizations (Abid et al. 2015; GÜÇEL and Begec 2012) SL is applicable in banking sectors in developing countries (Mathur and Negi 2014). Moreover, managers and executives in the banking sector can apply SL to improve the OC of the employees which will, in turn, motivate the employees to do extra for organizations.

Organizations can inspire managers to follow the SL behavior to deal with their employees. Training and mentoring programs can develop the SL behavior among the managers (Liden et al. 2014; Peterson, Galvin, and Lange 2012). Managers can be trained in such a way that to deal with the employees they can exhibit personal attention, keep them knowledgeable about the development chances, establish a fair and open relationship with them, empower them, show sympathy to them for their faults, and provide credit to them for their achievements.

Employee-oriented leadership (SL) is the best option to deal with the highly educated and meritorious employees in the organization. Academicians must give more attention to the area of SL for more study. The course curriculum on leadership should also contain the model of SL.

\section{LIMITATIONS AND FUTURE RESEARCH DIRECTIONS}

Data collection using convenience sampling is the main limitation of the study that fails to generalize the results. All data were collected from only local PCBs of Bangladesh for ensuring data consistency. The sample consisted of only PCBs of Bangladesh, which seem to be more homogenous; thus, future researchers can cover other areas such as public banks, foreign banks to ensure heterogeneous demographics.

Among the respondents, ninety-nine percent hold a master's degree. The results of the study point out how to deal with highly educated people effectively. Thus, the results cannot be generalized how to deal with less-educated or working-class people effectively. Future researchers can cover the working-class people for exploring the influence of $S L$ on the job 
attitude of working-class people.

The objective perception of the employees rather than independent and subject measurement was used to measure the variables. The future researcher can use both subjective and objective measurements for generating undisputable results.

The present study did not reveal the impact of SL on the different dimensions of $O C$ and OCB. Future studies can explore the relationship of SL with different dimensions of $O C$ and $O C B$.

\section{CONCLUSION}

SL creates a positive attitude among employees since they are given importance by the leaders. In exchange for this leadership behavior, subordinates show their steady commitment to organizations and performing extra pro-social activities. Additionally, servant leaders can create a positive organizational context and culture that fosters $\mathrm{OC}$ and OCB. Business organizations are facing more challenges from technological progress and worldwide competition. In this situation, every business organization needs to adapt to the new technologies and increase competitiveness. Managers are now worried about how to develop and retain talented employees. SL is an excellent approach to lead employees with high potential and skills. SL can foster the affirmative postures and performance of the employees. Moreover, the organizational effort for increasing $O C$ will foster OCB through SL. Organizations can develop the SL through proper assessment, training, and mentoring programs according to the SL model. More specifically, SL development programs develop the managers to demonstrate personal consideration to their employees, keep them well informed about the development opportunities, establish a fair and open relationship with them, empower them, show empathy to them, and provide credit to the employees for their achievements.

\section{REFERENCES}

Abid, H. R., Gulzar, A., and Hussain, W. 2015. The impact of servant leadership on organizational citizenship behaviors with the mediating role of trust and moderating role of group cohesiveness; A Study of public Sector of Pakistan. International Journal of Academic Research in Business and Social Sciences, 5(3): 234.

Ahmed, O. and Rahman, B. 2020. Employees of Commercial Banks Learning to Unlearn: A Case Study on the Impact of Electronimic Banking in the Commercial Banks of
Bangladesh. International Journal of Business and Technopreneurship, 10(1): 31-50.

Allen, N. J., and Meyer, J. P. 1990. The measurement and antecedents of affective, continuance and normative commitment to the organization. Journal of occupational psychology, 63(1): 1-18.

Allen, N. J., and Meyer, J. P. 1996. Affective, continuance, and normative commitment to the organization: An examination of construct validity. Journal of Vocational Behavior, 49(3): 252-276.

Awee, A., Cheah, W. Y., Cheng, C. N., Hong, K. S., Ling, L. B., and Tan, M. C. 2014. Effect of servant leadership on affective commitment among hotel employees. International Journal of Scientific and Research Publications, 4(11): 1-7.

Baruch, Y., and Holtom, B. C. 2008. Survey response rate levels and trends in organizational research. Human relations, 61(8): 1139-1160.

Bobbio, A., Dierendonck, D. V., and Manganelli, A. M. 2012. Servant leadership in Italy and its relation to organizational variables. Leadership, 8(3): 229-243.

Borman, W. C., and Motowidlo, S. 1993. Expanding the criterion domain to include elements of contextual performance.

Brown, T. J., Mowen, J. C., Donavan, D. T., and Licata, J.W. 2002. The customer orientation of service workers: Personality trait effects on self-and supervisor performance ratings. Journal of marketing research, 39(1): 110-119.

Bryman, A. 2016. Social research methods: Oxford university press.

Bučiūnienè, I., and Škudienè, V. 2008. Impact of Leadership Styles on Employees' Organizational Commitment in Lithuanian Manufacturing Companies. 3(2): 57. doi: https://doi.org/10.2478/v10033-008-0015-7

Cantarello, S., Filippini, R., and Nosella, A. 2012. Linking human resource management practices and customer satisfaction on product quality. The international journal of human resource management, 23(18): 3906-3924.

Carroll, B. C., and Patterson, K. 2016. Servant leadership: A cross cultural study between India and the United States. Servant Leadership: Theory \& Practice, 1(1): 3.

Cerit, Y. 2009. The Effects of Servant Leadership Behaviours of School Principals on Teachers' Job Satisfaction. Educational Management Administration \& Leadership, 37(5): 600-623. doi: 10.1177/1741143209339650

Cerit, Y. 2010. The effects of servant leadership on teachers' organizational commitment in primary schools in Turkey. International Journal of Leadership in Education, 13(3): 301-317.

Cetin, S., Gürbüz, S., and Sert, M. 2015. A meta-analysis of the relationship between organizational commitment and organizational citizenship behavior: Test of potential moderator variables. Employee responsibilities and rights journal, 27(4): 281-303. 
CH Chan, S., and Mak, W. M. 2014. The impact of servant leadership and subordinates' organizational tenure on trust in leader and attitudes. Personnel Review, 43(2): 272-287.

Chen, Z. X., and Francesco, A. M. 2003. The relationship between the three components of commitment and employee performance in China. Journal of Vocational Behavior, 62(3): 490-510.

Cheung, G. W., and Lau, R. S. 2008. Testing mediation and suppression effects of latent variables: Bootstrapping with structural equation models. Organizational research methods, 11(2): 296-325.

Coleman, V. I., and Borman, W. C. 2000. Investigating the underlying structure of the citizenship performance domain. Human resource management review, 10(1): 25-44.

Drury, S. L. 2004. Servant leadership and organizational commitment. Paper presented at the Servant Leadership Research Roundtable.

Ferdus, Z., and Kabir, T. 2018. Effect of job satisfaction and organizational commitment on OCB: study on private banks in Bangladesh. World Journal of Social Sciences, 8(2): 57-69.

Greenleaf, R. 1970. The servant as leader (an essay). Greenleaf Organization.

GÜÇEL, C., and Begec, S. 2012. The effect of the servant leadership on organizational citizenship behavior: Case study of a university. International Journal of Social Sciences and Humanity Studies, 4(1): 107-116.

Hair, J. F., Black, W. C., Babin, B. J., Anderson, R. E., and Tatham, R. L. 2012. Multivariate data analysis (Vol. 6): Upper Saddle River, NJ: Pearson Prentice Hall.

Haque, A. K. M. T., Uddin, M. A., Easmin, R., and Sohel, S. M. 2019. Job Satisfaction and Citizenship Behavior: $A$ Mediating Effect of Organizational Commitment. 52(3): 236. doi: https://doi.org/10.2478/orga-2019-0015

Hoe, S. L. 2008. Issues and procedures in adopting structural equation modeling technique. Journal of applied quantitative methods, 3(1): 76-83.

Hopwood, C. J. 2007. Moderation and mediation in structural equation modeling: Applications for early intervention research. Journal of early intervention, 29(3): 262-272.

$\mathrm{Hu}$, J., and Liden, R. C. 2011. Antecedents of team potency and team effectiveness: An examination of goal and process clarity and servant leadership. Journal of Applied Psychology, 96(4): 851.

lacobucci, D., Saldanha, N., and Deng, X. 2007. A meditation on mediation: Evidence that structural equations models perform better than regressions. Journal of consumer psychology, 17(2): 139-153.

Irving, J. A., and Longbotham, G. J. 2007. Team effectiveness and six essential servant leadership themes: A regression model based on items in the organizational leadership assessment. International Journal of Leadership Studies, 2(2): 98-113.

Jahangir, N., Akbar, M., and Begum, N. B. 2006. The role of social power, procedural justice, organizational commitment, and job satisfaction to engender organizational citizenship behavior. ABAC Journal, 26(3): 21-36.

Ju Rebecca Yen, H., and Gwinner, K. P. 2003. Internet retail customer loyalty: the mediating role of relational benefits. International Journal of Service Industry Management, 14(5): 483-500.

Kashyap, V., and Rangnekar, S. 2014. The moderating role of servant leadership: Investigating the relationships among employer brand perception and perceived employee retention. Review of HRM, 3: 105-118.

Kline, R. B. 2005. Principles and practice of structural equation modeling 2 nd edition guilford press. New York.

Koyuncu, M., J. Burke, R., Astakhova, M., Eren, D., and Cetin, H. 2014. Servant leadership and perceptions of service quality provided by front-line service workers in hotels in Turkey: achieving competitive advantage. International Journal of Contemporary Hospitality Management, 26(7): 1083-1099.

Lapointe, É., and Vandenberghe, C. 2018. Examination of the relationships between servant leadership, organizational commitment, and voice and antisocial behaviors. Journal of Business Ethics, 148(1): 99-115.

Laub, J. A. 1999. Assessing the servant organization: Development of the servant organizational leadership (SOLA) instrument, Florida Atlantic University.

Lawrence, J., Ott, M., and Bell, A. 2012. Faculty organizational commitment and citizenship. Research in Higher Education, 53(3): 325-352.

Le Ng, X., Choi, S. L., and Soehod, K. 2016. The Effects of Servant Leadership on Employee's Job Withdrawal Intention. Asian Social Science, 12(2): 99.

Lee, A., Lyubovnikova, J., Tian, A. W., and Knight, C. 2019. Servant leadership: A meta-analytic examination of incremental contribution, moderation, and mediation. Journal of Occupational and Organizational Psychology.

Liden, R. C., Wayne, S. J., Liao, C., and Meuser, J. D. 2014. Servant leadership and serving culture: Influence on individual and unit performance. Academy of management Journal, 57(5): 1434-1452.

Liden, R. C., Wayne, S. J., Zhao, H., and Henderson, D. 2008. Servant leadership: Development of a multidimensional measure and multi-level assessment. The Leadership Quarterly, 19(2): 161-177.

Liu, B., Hu, W., and Cheng, Y. C. 2015. From the west to the east: Validating servant leadership in the Chinese public sector. Public Personnel Management, 44(1): 25-45.

Lloyd, B. 1996. A new approach to leadership. Leadership \& Organization Development Journal, 17(7): 29-32.

Luthans, F., and Favolio, B. 2003. Authentic leadership development. KS cameron, JE Dutton \& RE Quinn (Eds.), 
Positive organizational scholarship: Foundations of a new discipline, 241-258.

Mathur, G., and Negi, P. 2014. Servant Leadership and Organizational Citizenship Behaviour Among Employees of Service Sector. American International Journal of Research in Humanities, Arts and Social Sciences, 7(2): 191-196.

McGee-Cooper, A., and Looper, G. 2001. The essentials of servant-leadership: Principles in practice: Pegasus Communications Dallas.

Meyer, J. P., and Allen, N. J. 1991. A three-component conceptualization of organizational commitment. Human resource management review, 1(1): 61-89.

Meyer, J. P., Stanley, D. J., Herscovitch, L., and Topolnytsky, L. 2002. Affective, continuance, and normative commitment to the organization: A meta-analysis of antecedents, correlates, and consequences. Journal of Vocational Behavior, 61(1): 20-52.

Miao, Q., Newman, A., Schwarz, G., and Xu, L. 2014. Servant leadership, trust, and the organizational commitment of public sector employees in China. Public Administration, 92(3): 727-743.

Miller, K. 2003. Values, attitudes and job satisfaction. Organisational Behaviour: Global and Southern African Perspectives. Cape Town: Pearson Education South Africa.

Mirabizadeh, M., and Gheitasi, S. 2012. Examining the organizational citizenship behavior as the outcome of organizational commitment: Case study of universities in llam. Management Science Letters, 2(3): 951-960.

Moorman, R. H., Niehoff, B. P., and Organ, D. W. 1993. Treating employees fairly and organizational citizenship behavior: Sorting the effects of job satisfaction, organizational commitment, and procedural justice. Employee responsibilities and rights journal, 6(3): 209-225.

Morrison, E. W. 1994. Role definitions and organizational citizenship behavior: The importance of the employee's perspective. Academy of management Journal, 37(6): 1543-1567.

Morrow, P. C. 1993. The theory and measurement of work commitment: Jai Press.

Najafi, S., Noruzy, A., Azar, H. K., Nazari-Shirkouhi, S., and Dalv, M. R. 2011. Investigating the relationship between organizational justice, psychological empowerment, job satisfaction, organizational commitment and organizational citizenship behavior: An empirical model. African Journal of Business Management, 5(13): 5241-5248.

Neubert, M. J., Kacmar, K. M., Carlson, D. S., Chonko, L. B., and Roberts, J. A. 2008. Regulatory focus as a mediator of the influence of initiating structure and servant leadership on employee behavior. Journal of Applied Psychology, 93(6): 1220.

Newman, A., Neesham, C., Manville, G., and Tse, H. H. 2018. Examining the influence of servant and entrepreneurial leadership on the work outcomes of employees in social enterprises. The international journal of human resource management, 29(20): 2905-2926.

Newman, A., Schwarz, G., Cooper, B., and Sendjaya, S. 2017. How servant leadership influences organizational citizenship behavior: The roles of LMX, empowerment, and proactive personality. Journal of Business Ethics, 145(1): 49-62.

Ng, T. W., and Feldman, D. C. 2011. Affective organizational commitment and citizenship behavior: Linear and non-linear moderating effects of organizational tenure. Journal of Vocational Behavior, 79(2): 528-537.

Obedgiu, V., Bagire, V., and Mafabi, S. 2017. Examination of organizational commitment and organizational citizenship behaviour among local government civil servants in Uganda. Journal of Management Development.

op den Buijs, T., Broesder, W., Goldenberg, I., Resteigne, D., and Kivirähk, J. 2019. Warrior and peacekeeper role identities: associations with self-esteem, organizational commitment and organizational citizenship behavior. Journal of Military Studies, 8: 3-15.

Organ, D. 1988. Organizational citizenship behavior: The good soldier syndrome Lexington Books Lexington. Lexington, MA: Lexington Books.

Organ, D. W., Podsakoff, P. M., and MacKenzie, S. B. 2005. Organizational citizenship behavior: Its nature, antecedents, and consequences: Sage Publications.

Parris, D. L., and Peachey, J. W. 2013. A systematic literature review of servant leadership theory in organizational contexts. Journal of Business Ethics, 113(3): 377-393.

Peterson, S. J., Galvin, B. M., and Lange, D. 2012. CEO servant leadership: Exploring executive characteristics and firm performance. Personnel Psychology, 65(3): 565-596.

Podsakoff, P. M., MacKenzie, S. B., Lee, J.-Y., and Podsakoff, N. P. 2003. Common method biases in behavioral research: A critical review of the literature and recommended remedies. Journal of Applied Psychology, 88(5): 879-903.

Podsakoff, P. M., MacKenzie, S. B., Moorman, R. H., and Fetter, R. 1990. Transformational leader behaviors and their effects on followers' trust in leader, satisfaction, and organizational citizenship behaviors. The Leadership Quarterly, 1(2): 107-142.

Podsakoff, P. M., MacKenzie, S. B., and Podsakoff, N. P. 2012. Sources of method bias in social science research and recommendations on how to control it. Annual review of psychology, 63: 539-569.

Pooja, A. A., De Clercq, D., and Belausteguigoitia, I. 2016. Job stressors and organizational citizenship behavior: The roles of organizational commitment and social interaction. Human Resource Development Quarterly, 27(3): 373-405.

Porter, L. W., Steers, R. M., Mowday, R. T., and Boulian, P. V. 1974. Organizational commitment, job satisfaction, 
and turnover among psychiatric technicians. Journal of Applied Psychology, 59(5): 603-609.

Prasetio, A. P., Yuniarsih, T., and Ahman, E. 2017. Job satisfaction, organizational commitment, and organizational citizenship behaviour in state-owned banking. Universal Journal of Management, 5(1): 32-38.

Ramli, A., and Desa, N. M. 2014. The relationship between servant leadership and organizational commitment: The Malaysian perspectives. International Journal of Management and Sustainability, 3(2): 111-123.

Reed, L. 2016. Servant leadership, followership, and organizational citizenship behaviors in 9-1-1 emergency communications centers: Implications of a national study. Servant Leadership: Theory \& Practice, 2(1): 5.

Reichers, A. E. 1985. A review and reconceptualization of organizational commitment. Academy of management review, 10(3): 465-476.

Saunders, M., Lewis, P., and Thornhill, A. 2009. Research methods for business students: Pearson education.

Smith, C., Organ, D. W., and Near, J. P. 1983. Organizational citizenship behavior: Its nature and antecedents. Journal of Applied Psychology, 68(4): 653-663.

Van Dierendonck, D., and Nuijten, I. 2011. The servant leadership survey: Development and validation of a multidimensional measure. Journal of business and psychology, 26(3): 249-267.

Van Dierendonck, D., Sousa, M., Gunnarsdóttir, S., Bobbio, A., Hakanen, J., Pircher Verdorfer, A., . . Rodriguez-Carvajal, R. 2017. The cross-cultural invariance of the servant leadership survey: A comparative study across eight countries. Administrative Sciences, 7(2): 8.

Vandyne, L., Cummings, L. L., and Parks, J. M. 1995. Extrarole behaviors-in pursuit of construct and definitional clarity (a bridge over muddied waters). RESEARCH IN ORGANIZATIONAL BEHAVIOR: AN ANNUAL SERIES OF ANALYTICAL ESSAYS AND CRITICAL REVIEWS, 17: 215-285.
Walumbwa, F. O., Hartnell, C. A., and Oke, A. 2010. Servant leadership, procedural justice climate, service climate, employee attitudes, and organizational citizenship behavior: a cross-level investigation. Journal of Applied Psychology, 95(3): 517.

Wong, P. T., and Page, D. 2003. Servant leadership: An opponent-process model and the revised servant leadership profile. Paper presented at the Proceedings of the Servant Leadership Research Roundtable.

Yang, H. J., and Min, H. Y. 2013. The Relationship between Directors' Servant Leadership and Teachers' Organizational Citizenship Behavior: The Mediation Effect of Teachers' Psychological Empowerment in Childcare Centers. Korean Journal of Human Ecology, 22(6): 547-557.

Yen, C. H., and Teng, H. Y. 2013. The effect of centralization on organizational citizenship behavior and deviant workplace behavior in the hospitality industry. Tourism Management, 36: 401-410.

Zeinabadi, H. 2010. Job satisfaction and organizational commitment as antecedents of organizational citizenship behavior (OCB) of teachers. Procedia-Social and Behavioral Sciences, 5: 998-1003.

Zhang, Y., Lin, T. B., and Fong Foo, S. 2012. Servant leadership: A preferred style of school leadership in Singapore. Chinese Management Studies, 6(2): 369-383.

Zhou, Y., and Miao, Q. 2014. Servant leadership and affective commitment in the Chinese public sector:The mediating role of perceived organizational support. Psychological reports, 115(2): 381-395.

Zikmund, W. G., Babin, B. J., Carr, J. C., and Griffin, M. 2013. Research Business Methods. Boston: South-Western Cengage Learning. 